Матеріали науково-практично конференці з участю міжнародних спеціалістів «Актуальні питання діагностики, лікування, раціонально фармакотерапі, диспансеризаці та реабілітаці в практиці сімейного лікаря»

УДК 611.018.4-008.6-02:616.33/.342-06:616.37-002-036.1

\title{
ТРИВАЛІСТЬ ЗАХВОРЮВАННЯ ЯК ЧИННИК РОЗВИТКУ СТРУКТУРНО- ФУНКЦІОНАЛЬНИХ ЗМІН КІСТКОВО ТКАНИНИ У ХВОРИХ НА ХРОНІЧНИЙ ГАСТРОДУОДЕНІТ У ПОЄДНАННІ З ХРОНІЧНИМ ПАНКРЕАТИТОМ
}

\author{
(Т. В. Бойко, Г. В. Лихацька, В. О. Лихацька
}

ДВНЗ «Тернопільський державний медичний університет імені І.Я. Горбачевського МОЗ України».

У хворих на поєднану патологію органів травлення часто розвивається остеодефіцит, що значно зростає внаслідок збільшення в популяці кількості людей літнього та старечого віку. Однак, повністю не з'ясовані механізми формування остеодефіциту, роль чинників ризику.

Мета роботи - вивчити тривалість захворювання як чинник розвитку структурно-функціональних змін кістково тканини у хворих на хронічний гастродуоденіт (ХГД) у поєднанні з хронічним панкреатитом (ХП).

Матеріали і методи дослідження. Обстежено 44 хворих на ХГД у поєднанні з ХП. Серед обстежених було 24 чоловіки (54,6\%) та 20 жінок (45,4\%). Середній вік хворих становив $(47,43 \pm 2,28)$ років. Поміж обстежених переважали хворі зрілого віку 15 осіб (34,1 \%). Хворі були поділені, згідно з рекомендаціями ВОО3, на три групи: І групу становили $12(27,3 \%)$ пацієнтів з нормальною МЩКТ, II групу $23(52,3 \%)$ обстежених 3 остеопенією, III групу $9(20,4 \%)$ осіб з ОП. У кожній групі проводили детальну оцінку основних денситометричних показників та аналізували х для встановлення чинників ризику розвитку остеодефіцитних станів за наявності ХГД у поєднанні з ХП. Для верифікаці діагнозу використовували широкий спектр клінічних і лабораторно-інструментальних обстежень (загальний та біохімічний аналізи крові, сечі, копрограма, імуноферментний аналіз крові на виявлення антитіл до Нр, у частини хворих ПЛР на виявлення Нp і вірусів гепатитів B, C, езофагогастродуоденофіброскопія з гістологічним та цитологічним дослідженням, ультразвукове дослідження органів черевно порожнини, денситометричне обстеження поперекового відділу хребта та проксимального відділу право стегново кістки, яке проводили на апараті Lunar (США).

Результати й обговорення. Під час вивчення впливу тривалості захворювання на розвиток остеопенічного синдрому та остеопорозу в обстежених пацієнтів виявлено, що із збільшенням тривалості хвороби зростає частота виникнення та поглиблюється остеодефіцит. Так, усі пацієнти з остеопорозом страждали на ХГД у поєднанні з ХП більше 10-ти років, а поміж хворих з нормальним станом КТ більше половини $(58,3 \%)$ було з тривалістю захворювання до 5 років. Оцінка структурнофункціонального стану КТ залежно від тривалості захворювання показала достовірне зниження всіх показників МЩКТ при збільшенні давності хвороби. Так, у хворих з тривалістю хвороби більше 10-ти років показники мінералізаці кістки знизилися на 13,8 та 22,9 \%, порівняно з хворими, що страждають на недугу від 6 до 10 та до 5 років відповідно.

Таким чином, велика частота виявлення остеодефіцитних станів (у 72,7 \% обстежених) ще раз вказує на важливість проведення денситометричних досліджень.

Висновки: 1. Глибина змін мінерально щільності кістково тканини за умов хронічного гастродуоденіту в поєднанні з хронічним панкреатитом залежить від тривалості захворювання.

2. Встановлена гетерогенність поширеності структурно-функціональних змін кістково тканини та залежність остеодефіциту у хворих на дану мікстпатологію від тривалості захворювання.

Перспективи подальших досліджень полягають у вивченні інших чинників ризику у хворих на хронічний гастродуоденіт у поєднанні з хронічним панкреатитом. 